\title{
LOFTY BUT NOT POWERFUL: A CRITICAL ANALYSIS OF THE POSITION OF THE GENERAL ASSEMBLY IN THE UNION OF THE CHURCH OF CENTRAL AFRICA PRESBYTERIAN (MALAWI)
}

\section{Rhodian Munyenyembe ${ }^{1}$}

Department of Church History, Free State University

\section{Johannes Wynand Hofmeyr}

Department of Church History, Free State University

linhof@mweb.co.za

\section{ABSTRACT}

In this article the specific focus is on the position of the General Assembly in the Church of Central Africa Presbyterian (CCAP) in Malawi. Though the General Assembly was meant to foster a closer unity of the constituent synods, it still remains an unstable entity, and has been so over the years due to the autonomy of the synods; much more so in recent years because of disputes among the synods. This especially applies to the border disputes between the Synod of Livingstonia and the Nkhoma Synod. Though the 2013 General Assembly has somewhat healed the tension, the future of the General Assembly is likely not to be a vibrant one as long as the synods do not fully surrender their autonomy to a body that is supposed to be above them administratively. However, this appears not to be the synods' option in the nearest future, thereby perpetuating the loftiness of the General Assembly without its accompanying powers.

Keywords: Church of Central Africa Presbyterian (CCAP); Malawi; General Assembly; unity; independent synods; disputes; Nkhoma; Livingstonia

1 Article based on a $\mathrm{PhD}$ dissertation submitted to the University of the Free State, Oct 2015 under promotorship of Prof. J.W. Hofmeyr, Extraordinary Professor, Department of Church History, University of the Free State.

\section{UNISA}




\section{INTRODUCTION}

Having been formed in 1924, the Church of Central Africa Presbyterian (CCAP), as an ecumenical denomination, has been operating under various union bodies, eventually culminating into the General Assembly, which is the embodiment of the union today. This article aims at showing how unstable the General Assembly is as a unifying body of the CCAP in view of the powers that its synods have. The authors argue that since the synods decided to retain autonomy from the time the union was formed, there has never been real power in the General Assembly despite its loftiness, which renders the unity itself less viable.

\section{THE GENERAL ASSEMBLY AND ITS MEETINGS}

The General Assembly is an umbrella body of five synods of the CCAP, namely Livingstonia, Blantyre, Nkhoma, Harare and Zambia. It meets every four years and it is convened by the moderator or in his absence by the vice moderator. Apart from these regular meetings taking place once in every four years, the General Assembly may be convened by the moderator or his vice in his absence, requesting an extraordinary session any time when matters arise requiring urgent attention and resolution. ${ }^{2}$ In the absence of the moderator or vice moderator the General Assembly meetings may be chaired by a locum chairman of the meeting. ${ }^{3}$

The 2002 Constitution of the CCAP General Assembly demands that all its decisions and resolutions be implemented by each synod without further ratification by the synod. It further warns that failure to implement such resolution shall be cause for disciplinary action against the failing synod. Realising that the synods may not always be willing to bind themselves to some decision and resolution of the General Assembly, the constitution provides the following provision:

The General Assembly, however, may in some cases when passing a resolution or decision require and specify that ratification of the resolution or decision by at least a maximum of $3 / 5$ of all synods is necessary before the concerned resolution becomes binding on all synods. The ratification or rejection by the synod must be communicated to the General Assembly within six months of the resolution. Failure to notify within this period shall be taken as ratification. ${ }^{4}$

In between the meetings of the General Assembly the executive work of the General Assembly is run by the General Assembly Standing Committee. This committee is composed of the General Assembly moderator, vice moderator, secretary general, two deputy secretary generals, the moderators and general secretaries of each synod

2 The Constitution of the Church of Central Africa Presbyterian General Assembly, 2002, section 8.7.2, paragraph 2 .

3 Ibid, section 8.7.3.

$4 \quad$ Ibid, section 8.7.5 paragraph no. 2 . 
and two church elders nominated by each synod. All these serve for a period of four years. The treasurer of the General Assembly also attends the standing committee meetings in an ex-officio capacity without voting powers. ${ }^{5}$

\section{COMMISSIONERS OF THE GENERAL ASSEMBLY}

The people who represent their synods at the General Assembly are referred to as commissioners. In keeping with the Presbyterian tradition, which emphasises the rule of the church by elders, the General Assembly delegates consist of equal numbers of ministers and elders from each synod. In the current constitution different synods have a different number of delegates that they can send to the General Assembly meeting. The three Malawian Synods of Livingstonia, Blantyre and Nkhoma are required to send 40 commissioners each (20 elders and 20 ministers) while the Synods of Zambia and Harare are required to send 10 commissioners each. ${ }^{6}$ Section 8.3.2 of the 2002 Constitution of the CCAP General Assembly stipulates that the number of commissioners (as explained in section 8.3.1) may be changed from time to time by a resolution of the General Assembly or its Standing Committee. In an interview with the current moderator of the General Assembly, Rt. Rev. Dr T.P.K. Nyasulu, he mentioned that the Synods of Zambia and Harare are now sending 20 delegates as commissioners to the General Assembly meeting. ${ }^{7}$ It can, therefore, be assumed that the provision of section 8.3.2, 2002 Constitution of the CCAP General Assembly, has been in use since the constitution was adopted in 2002. According to the current General Assembly moderator, the decision to have different numbers of delegates for different synods was reached depending on the sizes of the synods. It is a well-known fact that the Malawian synods of the CCAP are far bigger than their sister synods in Zambia and Harare.

The constitution also recognises the General Assembly moderator, vice moderator, the secretary general and the deputy secretary general as commissioners from their particular synods for purposes of determining the total number of commissioners from each synod. Special church ministries such as the Women's Guild, Men's Guild and the Youth also have a representative each. However, their representative is supposed to be a church elder by rank. ${ }^{8}$

\section{ATTEMPTS AT EMPOWERING THE GENERAL ASSEMBLY}

5 Ibid, section 9.4 (closing paragraph).

6 Ibid, section 8.3.1.

7 Rt. Rev. Dr T.P.K. Nyasulu, General Synod Moderator, interview, 20.11.14.

8 See: The Constitution of the Church of Central Africa Presbyterian General Assembly, 2002, sections 8.3.1 and 8.3.3. 
The General Assembly cannot be seen to have any powers if it is not engaging with the synods and the lower courts of the church down to the congregational level as an umbrella body of the CCAP. Its task would be better realised if it were possible for it to be coordinating all the functions of the synods. It has to be pointed out though, that so far this has not been possible, partly due to inadequate funding on the part of the General Assembly as an umbrella body. There are constitutional provisions for the General Assembly to establish desks which would synchronise the various tasks of the CCAP synods. So far none of these desks have been established. The functions for which the General Assembly would have established specialised desks include the following: mission; evangelism and interfaith; youth work; women's work; health; church and society work; relief and development work; education; communication and advocacy; and work regarding a men's desk. ${ }^{9}$

It is expected that if these desks can be established, the synods are supposed to support them with human, material and financial resources in such a form and to the extent as the General Assembly Standing Committee may determine from time to time. ${ }^{10}$ The constitutional proposal is that these desks should be manned by ministers or lay people who are seconded by their synods or directly engaged by the General Assembly. With regard to their physical offices, they may either be at the General Assembly's secretariat or at the offices of the sending or sponsoring synod. It is expected that these desks should be holding church conferences with delegates from the synods and ultimately present their resolutions to the General Assembly or the General Assembly Standing Committee for consideration and action. ${ }^{11}$

All this shows that on paper there are grand plans for empowering the General Assembly and that the aspirations of its members are thereby known. However, when it comes to implementation, things seem not to work according to the members' expectations. With regard to the individual synods making contributions of money and personnel to various desks of the General Assembly, it is a well-known fact that that it would be stretching the synods' resources too much since some of the wellestablished departments in the synods themselves are greatly challenged by lack of personnel and inadequate funding. It would, therefore, not be easy for them to make substantial contributions to the General Assembly when they cannot meet their own needs.

During the General Synod era the mandate of the General Synod, in speaking on behalf of the synods, was confined to four areas as listed below: ${ }^{12}$

1. To warn the congregations of evils tending to invade the church.

2. Marriage regulations.

$9 \quad$ Ibid, section 8.13 .

10 Ibid.

11 Ibid.

12 Constitution of the Church of Central Africa, Presbyterian 1956, section 30(4). 
3. Relations with other churches.

4. Legislation which conflicts with the word of God.

On the above matters, according to the phraseology of the 1956 Constitution of the CCAP, which governed the administration of the General Synod up to 2002, it was stated that 'the synods shall...have power to delegate authority to the General Synod to speak in the name of the whole church on such matters' ${ }^{13}$ By contrast, in introducing the issues alluded to above, the 2002 Constitution of the CCAP General Assembly, which currently governs the General Assembly, states that: 'The General Assembly shall have power to speak in the name of the whole church on the following and other matters. ${ }^{14}$ In the first place, the General Assembly gives itself power over and against the synods so that the synods do not delegate power to the General Assembly, as was the case when the union was under the General Synod. Besides, by adding the phrase 'and such matters', the General Assembly is leaving the door open to whatever other matters it may want to speak out on behalf of the synods in trying to enhance CCAP unity in ecclesiastical pronouncements. Moreover, the list in the 2002 Constitution of the CCAP General Assembly adds a fifth item in the words 'serious matter of national interest or concern'. ${ }^{15}$ This last clause is the justification for the General Assembly's involvement in socio-political critique, especially when it comes to issuing press statements on some pressing issue in society, or when writing pastoral letters that comment on socio-political matters in the country, in the church's bid to fulfil its prophetic role.

It is the intention of the General Assembly to see greater unity and uniformity among the synods of the CCAP. Its constitution therefore mandates the General Assembly to endeavour to achieve uniformity and harmony in such matters as the training of ministers; catechetical instruction; prevention of evils which corrupt the people such as alcohol drinking, gambling, drug abuse, heathen initiations and other such things; education; medical work; ordering of public worship; dispensing of the sacraments; funeral rites; criteria for selecting church elders and deacons, women's guild; and recognition of church officers. ${ }^{16}$

Besides the above areas, the 2002 Constitution of the CCAP General Assembly also intended that the liturgies and rules of the synods be harmonised. In this regard, there was a need to generate uniformity across the synods regarding such things as the order of service and the various liturgical instruments. This was supposed to be done very quickly after the adoption of the 2002 Constitution of the CCAP General Assembly, and synods were asked to send their documents to the General Assembly

13 Ibid.

14 The Constitution of the Church of Central Africa Presbyterian General Assembly, 2002, Constitutional Schedule, section 4.5.

15 Ibid, section 4.5.5.

16 Ibid, section $4.5 \mathrm{ff}$. 
for scrutiny and evaluation by the Liturgy Committee, which had been formed to steer the process. ${ }^{17}$ Practically this would ensure that when members transfer from one synod to another they would be subject to similar rules and regulations to the ones they are familiar with. ${ }^{18}$

This article contends that, though the General Assembly would like to strengthen itself and promote the unity of the CCAP under its umbrella, the reality on the ground is counteracting this direction. In trying to understand why this is so, the study at hand suggests that the root of this failure for the General Assembly to assert itself with vigour, is the autonomy of the synods. This means that in so far as the synods shall maintain their autonomy, it will be difficult for them to voluntarily place themselves under the authority of the General Assembly. Consequently, it becomes very clear that the direction the CCAP General Assembly wants to go, cannot just be determined by constitutional provisions. Something needs to be done beyond or alongside constitutional provisions if true unity and uniformity is to be achieved. As it were, the constitution indeed stipulates that the highest court of the church is the General Assembly, and that it has authority to formulate policy for the church and to oversee and direct the synods and lower courts. ${ }^{19}$ However, without real executive power, the General Assembly shall remain an ineffective authority and an auxiliary organisation among the autonomous and relatively well organised synods.

\section{THE EFFICIENCY OF THE GENERAL ASSEMBLY VERSUS THE AUTONOMY OF THE SYNODS}

While the synods want the General Assembly to be efficient, it may be that they do not realise that while they are maintaining their autonomy, it may not facilitate the empowerment of the CCAP to have a vibrant General Assembly. There are reminiscences among some senior ministers in the CCAP to the effect that the General Assembly Secretariat was efficient and vibrant in the past during the tenures of Rev. W.P. Chibambo and those who followed him. These ministers, therefore, hanker for this golden age gone by when the General Assembly (still known as the General Synod) was vibrant and efficient and the Secretariat was a true representation of CCAP unity. What these ministers forget, though, is that the General Synod did not bother much with the way the synods were being administered, and there was little effort to try and unite the synods by proposing some kind of radical uniformity, as is the case in the 2002 Constitution of the CCAP General Assembly. One elderly minister of the Synod of Livingstonia confessed that during the General Synod era not many differences among the synods were known and people did not care

17 Ibid, section 4.3.

18 Ibid, section 4.3.

19 See: The Constitution of the Church of Central Africa Presbyterian General Assembly, 2002, Constitutional Schedule, section 6.6. 
much whether there were differences or not. ${ }^{20} \mathrm{He}$, however, notes that with the changes that were proposed in the then new 2002 Constitution of the CCAP General Assembly and the desire to initiate some uniformity, the synods realised that there were pronounced differences among them and they could not just easily sacrifice their long cherished traditions and distinctives for the sake of a uniform CCAP under the General Assembly. ${ }^{21}$ This means that until the change to the General Assembly demanded true unity and uniformity of the CCAP, synods did not realise how much they were going to lose as synods while gaining a General Assembly. No wonder there has been resistance (though subtle, but effective) on the part of the synods, as can be seen by their reluctance to change towards a more unified and uniform CCAP identity and character. For example, to make the liturgy uniform would be a very easy matter for the synods, but that has not materialised even though it has been promoted for decades that the liturgies are to be synchronised. ${ }^{22}$

\section{Lack of adequate funding for the General Assembly}

In accordance with constitutional provisions the General Assembly is supposed to have its own budget in order for it to support operations within its jurisdiction for mission work abroad. ${ }^{23}$ This budget is supposed to be approved by the General Assembly Standing Committee. It is interesting to note that synods are expected to make contributions towards the General Assembly budget annually. Constitutionally, these budgetary contributions by the synods are supposed to be made in two instalments in a year, that is, in the months of January and July. ${ }^{24}$ This means that the sustainability of the General Assembly largely depends on the ability and willingness of the synods to make contributions to its budget.

Apart from the contributions from member synods, the General Assembly also receives donations from well-wishers within the country and from foreign donors. With regard to money coming from foreign donors, the General Assembly benefits, but this is subject to good working relations among the synods. For example, the Reformed Mission League of the Netherlands has always been funding the General Assembly but due to inter-synodical wrangles, especially the dispute between the Synods of Livingstonia and Nkhoma, which rendered the General Assembly inactive

20 Rt. Rev. K.R.M. Nyirenda, Synod of Livingstonia minister, Mzuzu, interview, 12.12.14.

21 Ibid.

22 The call for the synchronisation of the liturgy can be seen even in the minutes of the General Synods meetings of the 1970s up to the 1990s. For example see: The CCAP, Minutes of the General Synod Held at Chongoni from 9 to 13 November 1994 (Moderator's Keynote Address, F. $2[\mathrm{f}]$, p. 18).

23 The Constitution of the Church of Central Africa Presbyterian General Assembly, 2002, section 8.8 .

Ibid. 
for some time, the funding stopped until the CCAP General Assembly was ready to put its house in order. ${ }^{25}$

A good amount of foreign funding also goes to Zomba Theological College, which is one visible sign of CCAP General Assembly unity, especially in the area of theological education, as a number of ministers from all the five synods of the CCAP train there. In recent years some synods have been establishing their own synodical theological colleges but they are still sending some of their theological students to the ecumenical Zomba Theological College. This means that funding from donor partners has to go to three different places, namely, synods, Zomba Theological College and the General Assembly. With regard to synods, each synod sends its own requests to partners in order to fund their budgets. Therefore, the same donor partners may receive budgetary support requests from various synods. Consequently, there is not much to set aside for the General Assembly, and it suffers from lack of adequate funding.

\section{Lack of adequate infrastructure}

While all the synods have relatively well-tended premises for their headquarters, the situation is different for the General Assembly. The General Assembly headquarters or Secretariat lacks well-furnished offices where the different departments or desks proposed for it could be working. While in the past a full time secretary general was manning the office, now the place is nearly abandoned except for the presence of security personnel guarding what is left after several raids by burglars. The previous caretaker of the office, Mr Kafumbi Njewa, retired from work in late November 2014, almost a year after the election of new office bearers. Although there were initiatives to have the secretary general settle in Lilongwe by December 2014, by 2015 the secretary general had not yet gone to stay in Lilongwe in order to command a powerful presence of the General Assembly. ${ }^{26}$

When the new leadership of the General Assembly visited the General Assembly offices in 2014 after their election in December 2013 at the Lundazi General Assembly meeting, they reportedly cried because of the pathetic situation of the premises they witnessed. ${ }^{27}$ They saw the place in a state of abandon due to the fact that the offices had been built some decades ago, coupled with the fact that due to the wrangles leading to the 2013 General Assembly meeting, the General Assembly Secretariat was not functional. This clearly shows that with regard to the sense of ownership, the synods do not seriously regard the General Assembly offices as their own. The relative seriousness with which the synods look after their own mission stations

25 Rt. Rev. T.P.K. Nyasulu, General Assembly Moderator and Synod of Livingstonia Education Secretary, Mzuzu, interview, 20.11.14.

26 Ibid.

27 Ibid. 
or headquarters does not translate to the General Assembly Secretariat, hence the neglect of the General Assembly premises.

The neglect of the General Assembly offices in Area 18 in Lilongwe is one of the signs of lacking unity and cooperation in the CCAP. The place and its infrastructure hardly qualify as the headquarters of the General Assembly. In this regard, the former General Secretary of Nkhoma Synod, Rev. Dr Winston Kawale, mused that the state of the General Assembly premises reflects the current picture of the CCAP ${ }^{28} \mathrm{At}$ closer look though, the premises seem to be worse than the church itself, but one can be excused for making the comparison. Lapani Nkhonjera testifies thus in his work concerning the General Assembly premises:

When I visited the place for the first time during my research work, I did not believe having reached such a high office by looking at its structures which look worse than some congregational offices of the CCAP. But no wonder this is a sign of how ineffective the office has been ( $\mathrm{sic}){ }^{29}$

The CCAP General Assembly premises tell the story of a body that is not taken seriously by its own members, as they are busy running their own business which looks more real and takes much of their time. The leadership of the CCAP appears to be mostly concerned with the synods and not with the General Assembly. Consequently, the General Assembly office has not seen any development since the present structure was built. Worse still, the place has all the signs of deterioration. ${ }^{30}$ The structure is at an open plot with no fence and no security features whatsoever. No wonder the windows and other fittings have succumbed to plundering over the years. When you visit the place sometimes you do not even find anybody there, though apparently there is supposed to be a caretaker. The situation at the General Assembly offices shows that it will take a very long time before the General Assembly can become an active player with a secretariat that is visible and working with good infrastructure and departments or centres that are vibrant.

\section{Lack of adequate personnel}

Apart from the ministers who are elected into several positions of the General Assembly, there are no people to serve in the various proposed desks as provided for in the constitution. This is a direct consequence of inadequate funding, because where an organisation is not well funded, it cannot employ the relevant personnel it requires. It has therefore remained the dream of the General Assembly, at least as provided for in its constitution, that several desks and projects be implemented with

28 Rev. Dr Winston Kawale, Lilongwe, interview, 14.5.14.

29 Lapani Nkhonjera, The Church of Central Africa Presbyterian: Formation and impact on its unity and disunity, BD, Zomba Theological College, 2008, p. 47.

30 For some pictures of the CCAP General Assembly office see the original dissertation. 
many people coming in from their respective synods and other places to work for the General Assembly; but with no realisation of this dream thus far.

\section{Inability to implement decisions}

Another problem with the General Assembly is its inability to implement decisions that are made during the General Assembly meetings. For decisions that are likely to bring change to be implemented, there is a need for strong leadership. One former General Secretary of one of the synods laments the passivity of the General Assembly secretariat, which according to him, is due to leadership incompetency and lack of management skills among pastors; some of whom are tasked with the mandate of leading the General Assembly. He laments that no one is strong enough to initiate the change, and so decisions gather dust without being implemented. ${ }^{31}$

Admittedly, it must be difficult for the General Assembly leadership to initiate much change, since they all come from their respective synods and they are expected to go back to them once their General Assembly responsibilities are over. It is, therefore, natural that they would be very much concerned with their synods, seeing that this is where their future lies, unlike the General Assembly, which they are likely to leave soon once their tenures expire. Besides, because of the inactivity of the General Assembly Secretariat, the elected leaders have been operating from their synods where they also hold responsibilities in either administration work or as pastors running congregations. ${ }^{32}$ In such a scenario, the position in the General Assembly leadership is looked upon as an extra responsibility on top of their most important synod work. ${ }^{33}$ Consequently, it is difficult for such people to commit themselves fully to the work of the General Assembly, which in any case has its offices far away from them, unless they are operating within Lilongwe.

\section{Lack of knowledge concerning the General Assembly among ordinary CCAP members}

The ordinary CCAP member is very much aware of his local congregation and the role of the moderator (who is always a minister) and the session clerk in the session, which is the administrative body at congregational level. From the session many Christians are aware of the presbyteries, though here the ordinary Christian is not very knowledgeable. When it comes to knowledge of their synods, many know a great deal about them. This means that the ordinary members know more about

31 Oral information, former General Secretary of one of the Synods in Malawi.

32 Rev. Colin M'bawa, General Secretary, CCAP General Assembly, phone conversation, 11.11.14.

33 For example the current General Assembly Moderator is the Education Secretary for the Synod of Livingstonia's Education Department, an equally demanding office. The General Secretary was still pastoring a congregation in Blantyre Synod almost a year after he was elected when the authors contacted him. 
their congregation and the synod, but little about their presbytery. However, when it comes to the General Assembly, there is just too much ignorance among the CCAP Christians. Many do not even know that such a body as the General Assembly exists. ${ }^{34}$ With regard to sister synods, they do know about them and they know that they are all part of the CCAP, but not many are aware that there is a body known as the General Assembly above the synods. Explanations for this state of affairs vary but they are basically condensed into three reasons, as explained below.

\section{Non-recognition of something above the synods}

The synods have developed in such a way that they do not recognise an authoritative body above them. Because of the way the Presbyterian system operates in the CCAP, it is generally assumed that the buck stops at synod level. It is, therefore, practically not easy to pass on authority to a higher body which is not fully recognised as having superiority over bodies that may be understood to be lower in rank. We argue that this failure to recognise the superiority of the General Assembly is the result of the General Assembly's inability to monitor what is happening in the synods. Moreover, its funding and personnel abilities are such that it cannot make its presence felt in the congregations, hence the lack of knowledge about the General Assembly among the grassroots Christians.

\section{Pronounced sense of synodical uniqueness}

While the leaders of the synods know that they are supposed to be united in one denomination despite belonging to different synods, there is always a tendency to emphasise what is unique about a particular synod. Usually these emphases go back to the culture of the founding missions with some feeling of pride that this synod, unlike its sister synods, was founded by such and such a church. For the Synod of Livingstonia, the emphasis is on the fact that its ethos is that of the Free Church of Scotland, despite the developments that have taken place over the course of history. In the same way, Blantyre Synod prides itself in being a 'child' of the Established Church of Scotland; and Nkhoma Synod too finds its unique identity in the South African Dutch Reformed Church roots worth clinging to. These distinctives, whether consciously or unconsciously, do eclipse the people's understanding that all the synods belong to the General Assembly because much energy and time is spent on emphasising these distinctives - to the neglect of what actually unites the synods into the CCAP today.

34 A random survey among ordinary Christians in the three synods conducted between 2012 and 2013 showed 90 per cent of the respondents expressing ignorance of the General Assembly, let alone its leadership. 


\section{Lack of civic education on the part of the leaders and the church members}

As a corollary to the above reasons, it has also been observed that there is lack of civic education on the part of the church members and even some leaders. The church members are not taught about the General Assembly and its role. It is, therefore, not surprising to see that they do not know about it. During services of worship in the CCAP churches, there comes a time when one member in the congregation rises to say the intercessory prayer. In this prayer many things are mentioned and in most cases the synods are specifically mentioned. In Malawi it is mostly the three Malawian synods that are singled out for specific mention in prayer, while at other times all five the synods are mentioned, depending on the knowledge of the person praying. In either case, the General Assembly is never mentioned. The surprising thing is that this happens not only when the person offering the intercessory prayer is an ordinary church member, but even when it is an elder, be it lay or ordained. Personal experience of one of the authors is that in all the times of attending the CCAP Sunday worship - in all three synods in Malawi over the years - only once did a Church leader lament the lack of knowledge about the General Assembly among congregants. This instance shows that the CCAP leadership has not made it their practice to tell Christians that they belong to the General Assembly, hence the ignorance.

\section{INTER-SYNODICAL WRANGLES AND THE STABILITY OF THE GENERAL ASSEMBLY}

On top of all the other challenges that the General Assembly faces, one of the biggest challenges is that of inter-synodical disputes, especially in relation to synodical boundaries. The most pronounced dispute is the one between the Synods of Livingstonia and Nkhoma. In line with the adage which says 'united we stand, divided we fall', the efficiency of the General Assembly is very much tied to the unity and good relations of the synods. Whenever the synods are not in accord, the General Assembly suffers heavy setbacks. It is because of this realisation that at each and every General Assembly meeting there are calls for greater unity and cooperation among the synods. While such calls are good for the sake of encouraging the members to seriously take care of their oneness in the General Assembly, the problem is that it becomes more like a song when there are no tangible results from the calls. From the beginning of the CCAP, tensions have been part of the life of the General Assembly. What is surprising, therefore, is not that there are disputes among the CCAP synods, but that there is any unity at all.

While disagreements have always threatened the existence of the General Assembly, the real threat to this unity was manifested in the years between 1996 and 2000, and again between 2007 and 2013. According to the view of the Synod of Livingstonia, Nkhoma Synod rejected the General Assembly resolutions on the 
border issue in 1967 and 1996, which seemed not to have been in Nkhoma Synod's favour. In view of these prolonged disagreements and frustrations, the Synod of Livingstonia took a very negative step in the year 1996 by deciding to pull out of the CCAP General Assembly. This was a very heavy blow to the stability of the General Assembly. This initial pull-out by the Synod of Livingstonia lasted up to the year 2000 when 'after a series of mediations' they decided to re-join the General Assembly, after being out of it for a period of four years. ${ }^{35}$

The second heavy blow to the stability of the General Assembly happened from 2007, when owing to inter-synodical disputes, the Synod of Livingstonia opted out of the $21^{\text {st }}$ General Assembly deliberations because, according to them, they were not given a chance to nominate a moderator, as it was their turn to do so. The position of Nkhoma Synod was that the existing leadership should continue leading the General Assembly until the border dispute issue had been resolved. Apparently, Nkhoma Synod was more comfortable to have a member of the Blantyre Synod leading the General Assembly as moderator than someone from the Synod of Livingstonia, with whom they were not on good terms owing to the border dispute. The General Assembly moderator at this time was the Rt. Rev. Dr Felix Chingota, and he continued chairing the meeting after the Synods of Blantyre and Nkhoma had adopted the agenda of not starting the meeting with the election of new office bearers, as was the practice. Due to their disappointment at what they considered to be constitutionally and traditionally unprocedural, delegates from the Synod of Livingstonia decided to make themselves mere observers of the deliberations. It is interesting to note that at this time the Synod of Livingstonia delegates felt 'betrayed' by their Blantyre Synod colleagues, whom they usually consider closer to them than those of Nkhoma Synod due to their Scottish connections. The then General Secretary of the Synod of Livingstonia did not hide his feelings when sharing the issue with their partner churches:

To the astonishment of the delegates from Livingstonia, the proposal from Nkhoma Synod was strongly supported and backed by Blantyre Synod...All the delegates from Blantyre and Nkhoma Synods voted against passing the office to Livingstonia. Only one delegate from Blantyre voted that it was time for the chair to be passed on to Livingstonia. ${ }^{36}$

On the fourth and last day of this meeting, the General Assembly requested the Synod of Livingstonia to rescind its decision and participate in the election of new office bearers, but the Synod of Livingstonia delegates would have none of it. Since this was a stalemate, as the mandate and authority of the new office bearers could be

35 Synod of Livingstonia, Solution to the border dispute between Nkhoma and Livingstonia Synods, Press release issued at the 30th Synod Assembly held at Bandawe Mission Station from 22 to 27 September 2006.

36 Rev. Howard Matiya Nkhoma, General Secretary, Synod of Livingstonia, email correspondence to all partner churches, Mzuzu, 29 January 2007. 
questionable, the General Assembly resolved to appoint former moderators, who are life members of the General Assembly, to act as a team of interim leadership until the time when new office bearers would be elected. The appointed former moderators were: The Very Rev. Dr S.S. Nyirenda from the Synod of Livingstonia, the Very Rev. K.J. Mgawi from Nkhoma Synod, Rev. G.J. Maseko from Nkhoma Synod and the Rt. Rev. Dr Silas Ncozana from Blantyre Synod. ${ }^{37}$ The then serving moderator, Rev. Dr Felix Chingota, was made part of the group and it is actually he who handed over the mantle of the General Assembly moderator to Rev. T.P.K. Nyasulu in 2013, when new office bearers were elected. ${ }^{38}$

The stalemate was also due to the fact that the Synod of Zambia declared that they would not participate in the election exercise because the General Assembly had denied the Synod of Livingstonia their turn to chair the Assembly through the provision of a moderator. Consequently, the Synods of Blantyre and Nkhoma could not form a General Assembly quorum since the Harare Synod did not attend this particular General Assembly meeting. Interestingly, the Synod of Zambia happens to be a 'child' of the Synod of Livingstonia, as it was Livingstonia missionaries who had established this brand of Christianity in Zambia. One can therefore argue that it was the affinity between the two that made the Synod of Zambia to sympathise and side with their Livingstonia colleagues.

The sad thing about the existence and efficiency of the General Assembly is that it had to take six years before another General Assembly meeting could take place. During this six year period the General Assembly, as it is known, became quite passive. As a result, even the General Assembly secretariat offices in Lilongwe were neglected. No wonder the newly elected leaders cried when they visited the premises during their familiarisation tour. ${ }^{39}$

The current top-most General Assembly leadership has Rt. Rev. Dr T.P.K. Nyasulu from the Synod of Livingstonia as moderator ('moderator general') and Rev. Collin M'bawa from Blantyre Synod as secretary general. These were elected at the General Assembly's $22^{\text {nd }}$ meeting held at Lundazi in Zambia from 13 to 15 December 2013. ${ }^{40}$ As would be expected, even during this meeting 'differences of perspectives were acknowledged while the desire for unity was widely and repeatedly emphasised'. ${ }^{41}$ This observation by Collins (2013) is in line with the current study's general view that whenever the General Assembly meets, there are calls for unity,

37 Ibid.

38 Rt. Rev. Dr T.P.K. Nyasulu, interview, 20.11.14.

39 Ibid.

40 James Chimpweya, Rev. Nyasulu is General Assembly Moderator, The Nation newspaper, 29 December 2013. Also The Nation online, http://mwnation.com/reverend-nyasulu-generalassembly-moderator/1of2.php.

41 Nancy Collins, Malawi: A report on the recent CCAP General Assembly, 18 December 2013, www.pcimissionoverseas.org/news/item/635/malawi-a-report-on-the-recent-ccap-generalassembly/. 
which is not surprising, given the unstable position of the General Assembly over the decades.

Though not much can or should be promised, it is pleasing to note that despite the differences in the stands of the synods, the $22^{\text {nd }}$ General Assembly meeting revived the desire for the unity of the church and renewed the synods' commitment to the unity of the CCAP in the General Assembly. Some leaders have testified that even the atmosphere of this meeting was pleasing and uplifting, so much so that delegates felt that they really belong to one denomination despite differences in their synods. ${ }^{42}$ In a way, this meeting was also corrective of the past disagreements from the 2007 meeting, when the Synod of Livingstonia missed its turn to chair the General Assembly by providing a moderator. Noteworthy is the fact that all the synods were present at this meeting and support for the election of the new office bearers was overwhelming - even from synods that would otherwise have been against candidates from their considered rivals. In this regard, Nkhoma Synod's support for the Synod of Livingstonia's candidate, Rev. Dr T.P.K. Nyasulu, as moderator, was more than edifying. ${ }^{43}$

\section{PARTNER CHURCHES AND THE STABILITY OF THE GENERAL ASSEMBLY}

The question is whether some of the foreign partners' policies do contribute to the unstable position of the General Assembly. In the words of some oral informants who happen to be leaders in the denomination, the foreign partners too share the blame for the failure of the General Assembly to be a vibrant union. In the first place, the blame goes back many years to the time of the moratorium when the missions were handing over the leadership of the church to the indigenous leaders. According Rev. Dr K.J. Mgawi, the first indigenous general secretary of Nkhoma Synod, the missionaries or mother churches of the missions contributed to the problems that the General Assembly is facing today. ${ }^{44}$ Mgawi claims that the indigenous leaders inherited a church that was not fully united because the expatriate leaders had not dealt with the issue of total union of the synods fully before handing them over to the local leaders. The local leaders were, therefore, not able to initiate further unification, especially in view of the fact that the mother churches had committed themselves to keep on helping their former missions (now turned daughter churches) with money, personnel and other resources. This meant that even though the local churches were now independent, their independence was not total because they still had to rely on

42 Reverend Levi N. Nyondo, General Secretary, Synod of Livingstonia, Mzuzu, oral information, 5.9.14.

43 Rt. Rev. T.P.K. Nyasulu, General Assembly Moderator and Synod of Livingstonia Education Secretary, Mzuzu, interview, 15.11.14.

44 Rev. Kilion Mgawi, First General Secretary of Nkhoma Synod, Nkhoma, interview, 21.2.14. 
or expect assistance from the mother churches. Consequently, the synods do not fully face towards the unity of the CCAP but towards their various partners who still fund them and give them some direction even today. Some church leaders even claim that the foreign partners favour different synods so much so that not all of them can be trusted to ensure that the General Assembly remains operational, to the extent of eclipsing the individual synods. It has to be confessed that this is a very tricky and complex issue and that it perhaps involves personalities more than hidden agendas of the foreign partners in question. The fact remains that 'he who pays the piper dictates the tune', and so the influence of the foreign partners cannot be ignored when we consider that theirs is the financial muscle.

\section{POLITICAL MACHINATIONS AND THE STABILITY OF THE GENERAL ASSEMBLY}

It is a fact that the bigger churches in Malawi exert some political influence in the country, which makes politicians try by all means to gain some sympathy or even support from these churches, especially their leaders. In situations where the government is not doing the right thing, the bigger churches sometimes write pastoral letters which end up damaging the reputation of the party in government - or even in the opposition if it becomes very clear that the problems rocking the country are coming from the opposition parties. Politicians, therefore, realise the importance of endearing themselves to prominent church leaders, in the hope of lessening the critical stance of the churches on their governance performance. In view of this scenario this study has observed that the synods are sometimes forced to work in a spirit of antagonism with each other because of the political pressure bearing on the churches' leadership. Of course this comes as a temptation to some individuals in the leadership of the churches, as sometimes they do not even realise that they are being ensnared. ${ }^{45}$ Consequently, the synods are divided when it comes to voicing out on pertinent issues in society. This explains why some synods have written pastoral letters on their own without involving their sister synods in the General Assembly in order to have a united CCAP voice. Moreover, the sister synods that have not issued the critical pastoral letter have opted not to make any official responses to such pastoral letters as a sign of maintaining political neutrality.

45 Moses Mlenga mentions an interesting testimony with regard to the tenure of office of Rev. Dr O.P. Mazunda of Livingstonia Synod, who served between 1992 and 2000 that he left the office 'a frustrated man because he was being accused of being too close to the President [Dr Bakili Muluzi] and the United Democratic Front (UDF)'. See: Moses Mlenga, History of Livingstonia Mission: 50 years of most-missionary leadership, 1958-2008, Zomba: Kachere, 2012, p. 24. Of course the former General Secretary does not hide the fact that they were and are still friends with Dr Bakili Muluzi (Oral information, Ekwendeni, 2013). It was, therefore, not surprising to see Rev. Dr O.P. Mazunda contesting as an aspiring councillor of one of the wards in Mzuzu City under the banner of the UDF party in the 2014 general elections. 
During the presidency of Dr Bingu wa Mutharika some leaders in the synods even approached the late president in the company of some party gurus, asking him to intervene in the inter-synodical disputes by using his executive powers. In his wisdom, the late president is said to have declined to have anything to do with church disputes because in his view, church disagreements are very volatile and have the potential to throw the country into chaos. ${ }^{46}$ This was the president's official position. However, besides the official position, the president is said to have bared his soul to some church leaders on the inter-synodical disputes, explaining their advantage at that time to his party and thereby taking sides. ${ }^{47}$

It is obvious that politicians use divide and rule tactics to influence certain individuals in the churches. Once some of the church leaders have been co-opted by politicians they tend to do things that are against the church's mandate because temptations to please their political masters become great. This therefore means that political forces, though quite subtle, have a significant bearing on the failure of the synods to fully unite for the effectiveness and efficiency of the CCAP General Assembly.

Private initiatives at reconciling the synods and strengthening the General Assembly

Close to the end of the year 2011 there was a group comprising 20 members from all three Malawian synods, which also wanted to initiate some inter-synodical dialogue for the sake of unity in the CCAP. One prominent member in this group was Professor Kings Phiri, who at one time chaired the Commission of Inquiry which looked into the border issue between the Synods of Livingstonia and Nkhoma under the auspices of the General Assembly. Other prominent members were Professor Kanyama Phiri, a renowned academic and the current Vice Chancellor of the Lilongwe University of Agriculture and Natural Resources (LUANAR), and Rev. Takuze Chitsulo of Blantyre Synod, among others. ${ }^{48}$

This grouping decided to call itself Forum for CCAP Unity (FCU) and it launched its activities in Blantyre in November 2011. Interestingly, the leaders of all three synods of the CCAP in Malawi expressed pessimism at the success of this grouping, fearing that it will be a tall order for all the concerned parties to reach a compromise on the issue under dispute. ${ }^{49}$ According to the Malawi News of December 24-30, 2011, the General Secretary of the Synod of Livingstonia, Rev. Levi Nyondo, dismissed the legitimacy of this grouping, arguing that it did not follow Presbyterian channels and procedures when coming up with the initiative. When contacted by

46 Rev. Levi N. Nyondo, General Secretary, Synod of Livingstonia, Mzuzu, oral information, 5.9.14.

47 Oral information from a minister who was present in the meeting. Name withheld.

48 See: Golden Matonga, Livingstonia Synod snubs dialogue initiative, The Guardian, Wednesday 7 December -Thursday 8 December 2011, pp. 1-2.

49 Archibald Kasakura, Synods giving up on border row: Leaders admit uniting Nkhoma and Livingstonia not a stroll in the park, Malawi News, December 24-30, 2011, pp. 1, 3 and 6. 
the said newspaper, Rev. Takuze Chitsulo, the group's secretary, contended that the group remained focused and could not be blamed of breaking protocol. He thus argued:

Our grouping is an independent entity. As such it would not be wise to align ourselves with structures of the same institutions that we are [mediating]. The most important thing is that we have alerted the leadership of all synods about our existence...we aim to see that at the end of the day our synods are working in harmony. ${ }^{50}$

Rev. Nyondo, however, acknowledged the importance of the group's intention, though in his capacity as General Secretary of the Synod of Livingstonia he could not appreciate the position of the group in the CCAP hierarchy.

As for the Rev. Davidson Chifungo, who was the General Secretary for Nkhoma Synod then, he observed that the success of FCU depended on their being accepted by all synods and also on the strategies that they would use. ${ }^{51}$ For him it was important that some people could take such an initiative for the sake of having unity in the Church, which he claimed Nkhoma Synod fully supported. ${ }^{52}$

Speaking on behalf of Blantyre Synod, Rev. Alex Maulana, General Secretary, believed that the emergence of such a group was complementary to the prayer for practical unity, which according to him, Christ preached. ${ }^{53} \mathrm{He}$, however, blamed fellow church leaders for failing to humble themselves in order for a solution to be found, lamenting that the gospel of unity and reconciliation seemed to be falling off the church's spiritual agenda. ${ }^{54}$

The above scenario shows that the failure of the General Assembly to experience practical unity is a thorn in the flesh as far as the oneness of the CCAP denomination is concerned, hence the many attempts by individuals and groups to try and reconcile the synods. These attempts are happening in the context of the Synods of Livingstonia and Nkhoma having already concluded that the solution to the border dispute is to ignore the borders so that the General Assembly becomes a unifying factor, irrespective of synodical boundaries, at least between Livingstonia and Nkhoma.

\section{CURRENT TRENDS IN THE GENERAL ASSEMBLY}

Since December 2013, there seems to be some peace in the General Assembly, especially as there are no more squabbles or disputes among the synods worth reporting in the newspapers. The Synods of Livingstonia and Nkhoma continue to

$50 \quad$ Ibid, p. 3.

51 Ibid, p. 6.

52 Ibid.

53 Ibid.

54 Ibid. 
establish churches in each other's territory with less eye-brows raised now as the practice has been there for some time and it seems people are beginning to consider it as something normal. This is so especially in the wake of Nkhoma Synod saying that they too would not recognise the boundary with Livingstonia. This reciprocal position by Nkhoma Synod in a way gives the Synod of Livingstonia some feeling of peace and confidence to go ahead with their planting of churches in what used to be Nkhoma Synod's exclusive territory, as their position now becomes less radical.

The other Synods of Blantyre, Zambia and Harare may not be very supportive of the new trend of not recognising synodical borders, but even for them peace in the General Assembly is something desirable. At present the fear of Blantyre Synod that Livingstonia and Nkhoma may want to invade Blantyre territory seems to be unfounded. The Synod of Livingstonia has made it very clear that she will not go into Blantyre Synod's territory. On the part of Nkhoma Synod, their message has not been very clear whether they would want to go to Blantyre. Despite sporadic differences that are experienced along the Blantyre Nkhoma boundary, the dispute has not reached a boiling point where one can liken it to the Livingstonia-Nkhoma wrangle. It is hoped that the relations will continue to improve.

With regard to having a united voice when commenting on socio-political issues in the country, it is now evident that there are some positive developments. For example the General Assembly managed to issue a statement in the year 2014 expressing dismay at the failure of government and the Malawi Broadcasting Corporation (MBC) to open up the public broadcaster to all political parties as the country was drawing closer to the May 20 tripartite elections. In the same vein, the General Assembly showed that the CCAP could sometimes unite, when on behalf of the synods it further condemned the scandal of looting public coffers in various government ministries otherwise known as Cashgate, which saw many donor partners withdrawing their aid from Malawi between 2013 and 2014. The General Assembly also condemned homosexuality in the same statement, arguing that the church's teaching is clear that a man marries a woman and vice versa. ${ }^{55}$

It is, therefore, becoming clear that in the new understanding of the General Assembly, the synods are trying to co-exist and make the General Assembly work despite their differences. It is yet to be seen how far this positive development will go, but with good leadership in the General Assembly it makes sense to say that the CCAP has spoken, rather than synods uttering their own statements. One CCAP leader is of the view that without the borders being recognised, the CCAP synods can continue to work harmoniously under the leadership of the General Assembly. ${ }^{56}$ An example is given of Scotland where there are no geographical boundaries of ecclesiastical jurisdictions but the church functions well under the General Assembly there. The

55 See: Frank Namangale, CCAP wants government to open up MBC, The Nation, March 29, 2014. Also The Nation online, www.nationmw.com, 19.3.14.

56 Rev. Levi N. Nyondo, General Secretary, Synod of Livingstonia, Mzuzu, oral information, 5.9.14. 
difference though is that in Scotland there are no synods; from the presbyteries they go straight to the General Assembly. This may explain why their General Assembly is not plagued with inter-synodical disputes.

\section{CONCLUSION}

The position of the General Assembly in the CCAP is an unstable one, and has been so over the years due to the autonomy of the synods, but much more so in recent years because of disputes among the synods. Though the 2013 General Assembly has somehow healed the tension, the future of the General Assembly is likely not to be a vibrant one as long as the synods do not fully surrender their autonomy to a body that is supposed to be above them administratively. And yet, this appears not to be the synods' option in the nearest future, thereby perpetuating the loftiness of the General Assembly without its accompanying powers.

\section{REFERENCES}

Chimpweya, J. 2013. Reverend Nyasulu is General Assembly Moderator. The Nation newspaper, 29 December. Also The Nation online, http://mwnation.com/reverend-nyasulu-generalassembly-moderator/1of2.php.

Collins, N. 2013. Malawi: A report on the recent CCAP General Assembly, 18 December. Also www.pcimissionoverseas.org/news/item/635/malawi-a-report-on-the-recent-ccap-generalassembly/.

Constitution of the Church of Central Africa, Presbyterian 1956, section 30(4).

Constitution of the Church of Central Africa Presbyterian General Assembly, 2002, Constitutional Schedule, section 4.5.5.

Kasakura, A. 2011. Synods giving up on border row: Leaders admit uniting Nkhoma and Livingstonia not a stroll in the park. Malawi News, December 24-30.

Matonga, G. 2011. Livingstonia Synod snubs dialogue initiative. The Guardian, Wednesday, 7 December -Thursday 8 December.

Mlenga, M. 2012. History of Livingstonia Mission: 50 years of most-missionary leadership, 19582008. Zomba: Kachere.

Namangale, F. 2014. CCAP wants government to open up MBC. The Nation, 29 March 29. Also The Nation online, www.nationmw.com, 19.3.14.

Nation Online, Livingstonia Synod needs discipline, www.mwnation.com, 17.4.13.

Nkhonjera, L. 2008. The Church of Central Africa Presbyterian: Formation and impact on its unity and disunity, BD, Zomba Theological College.

Synod of Livingstonia. 2006. Solution to the border dispute between Nkhoma and Livingstonia Synods. Press release issued at the $30^{\text {th }}$ Synod Assembly held at Bandawe Mission Station from 22 to 27 September, 2006. 
The Church of Central Africa Presbyterian, Minutes of the General Synod Held at Chongoni from 9 to 13 November 1994. (Moderator's Keynote Address, F. 2[f], p. 18).

The Nation newspaper, 2 December, 2010.

\section{Interviews}

Rev. H.M. Nkhoma, General Secretary, Synod of Livingstonia, email correspondence to all partner churches, Mzuzu, 29.1.07

Rev. K. Mgawi, First General Secretary of Nkhoma Synod, Nkhoma, interview, 21.2.14.

Rev. Dr W. Kawale, Lilongwe, interview, 14.5.14.

Rev. L.N. Nyondo, General Secretary, Synod of Livingstonia, Mzuzu, oral information, 5.9.14.

Rev. C. M'bawa, General Secretary, CCAP General Assembly, phone conversation, 11.11.14.

Rt. Rev. T.P.K. Nyasulu, General Assembly Moderator and Synod of Livingstonia Education, interview, 15.11.14.

Rt. Rev. T.P.K. Nyasulu, General Assembly Moderator and Synod of Livingstonia Education Secretary, Mzuzu, interview, 20.11.14.

Rt. Rev. K.R.M. Nyirenda, Synod of Livingstonia minister, Mzuzu, interview, 12.12.14. 